\title{
Marketable Branding in Surabaya Mayor Election 2015-2019
}

\author{
${ }^{1}$ Wahyuni Choiriyati, ${ }^{2}$ Ade Tuti Turistiati, ${ }^{3}$ Dinda Rakhma Fitriani \\ ${ }^{1}$ Universitas Pertamina, ${ }^{2}$ Universitas Amikom Purwokerto, ${ }^{3}$ Universitas Gunadarma \\ E-mail: wahyu_choiri@yahoo.com, ade.tuti@amikompurwokerto.ac.id, \\ dinda-rf@staff.gunadarma.ac.id
}

\begin{abstract}
Abstrak: Artikel ini adalah studi tentang teori dan konsep mengenai pemilihan walikota Surabaya 2015-2019. Pendekatan yang digunakan adalah studi komprehensif tentang pemasaran politik yang ditinjau oleh Lee Marshment pada tahun 2001. Surabaya menjadi objek tinjauan dalam artikel ini dengan berbagai keunikan proses sosialisasi Pemilihan Walikota atau Pilwali dengan memasang penghitung waktu dan berbagai lentera di Maskot Pilwali Surabaya 2015 untuk menargetkan pemilih pemula di Surabaya. Topik Marketable Branding adalah masalah strategis karena melibatkan cara lembaga politik ketika merumuskan produk politik, mengatur program publikasi kampanye dan komunikasi politik, serta strategi segmentasi untuk memenuhi kebutuhan masyarakat dengan perhitungan harga produk politik. Kondisi sosial-budaya dari wilayah geografis dan demografis juga harus diperhitungkan dalam segmentasi dan perumusan masalahmasalah politik. Surabaya mampu menjadi semacam model peran dalam persiapan politisi branding SWOT untuk daerah lain di Indonesia.
\end{abstract}

Kata kunci: marketable branding, strategi swot, pemasaran politik.

\begin{abstract}
This article provide a study of theories and concepts regarding the election of Surabaya mayor 2015-2019. The approach used is a comprehensive study of political marketing by Lee Marshment in 2001. Surabaya became the object of the review in this article with various uniqueness of the socialization process of Mayor Election or Pilwali by installing countdown timers and various lanterns in the 2015 Pilwali Surabaya mascot to target beginner voters in Surabaya. Marketable Branding topics are a strategic issue because they involve the way a political institution in formulating a political product, arranging a campaign publication program and political communication, and a segmentation strategy to meet the needs of the society to the price calculation of a political product. The sociocultural conditions of a geographical and demographic area must also be taken into account in the segmentation and formulation of political issues. Surabaya was able to become a kind of role modeling in the preparation of SWOT branding politicians for other regions in Indonesia.
\end{abstract}

Keywords: marketable branding, swot strategy, political marketing.

DOI: https://doi.org/10.29313/mediator.v12i2.5007 


\section{INTRODUCTION}

The capital city of East Java Province, known as the City of Heroes, in the regional structure of East Java Province was designated as the main center of East Java, at the same time was a first-order city. This is an indicator of the importance of Surabaya city to other cities in East Java. Its strategic location as the capital city of East Java Province, the economic center, maritime trade routes, and all other advantages of the city of Surabaya, making it a "sexy" city to be contested politically. The proof is Bambang Dwi Hartono (the twice former mayor of Surabaya) who was willing to reduce his position to become a deputy mayor, to just stay in power in the City of Heroes. The choice went to Tri Rismaharini, former Head of the Surabaya City Sanitation and Landscaping Service in 2010 whose name skyrocketed because of her Morality Politics.

In 2010 based on data from the Surabaya KPU (General Election Commission) in the 2010 Surabaya regional election, Tri RismahariniBambang DH won 358,187 votes or 38.53 percent. The main competitor of the pair Arif Afandi-Adies Kadir (CACAK) was in the second place with 327,516 votes or 35.25 percent. The pair Fandi UtomoYulius Bustami (Fu-Yu) ranked the third one with 129,172 votes or 13.90 per cent. In the fourth place occupied by BF Sutadi-Mazlan Mansur (Dimaz) who won 61,648 votes or 6.63 percent and finally, Fitradjaja Purnama-Naen Soeryono (independent) couple received 53,110 votes or 5.71 percent (Malang Post, 2015).

Communication politics observer from Airlangga University (Unair) Surabaya, Suko Widodo assessed, the winner of the 2010 Regional Election was not Risma, but the voice of 'golput' (non-voter) which reached 52 percent. According to Suko, most of the people in the abstentions group are from the upper-middle-class or who live in the elite housing, such as in the Citraland and Pakuwon. In addition, there are also immigrant communities from various regions in Indonesia. "These are immigrants, and metropolis residents who live in elite areas. Surabaya is a metropolitan city so it becomes a meeting point for the archipelago." (Berita Metro, 2015)

The observations from Suko Widodo certainly brought the fresh air of power for incumbent challengers in the final elections in 2015. It was the pair Rasiyo and Lucy Kurniasari, the candidate pair of mayors and deputy mayors of PAN (Partai Amanat Nasional), democratic bearer party who were the challengers of Risma-Whisnu in the election. The political constellation that still giving a victory gap from the community of abstentions in the election of mayors in the past five years has been used as a shed of votes which they have not touched and tried to win from an incumbent partner. Both of these pairs actually have a large influence in the city of Surabaya, although the percentage of the various RismaWhisnu survey institutions is still superior 70:30 compared to the Rasiyo-Lucy pair, and according to Bunnel, Miller, Phelps, and Taylor, "Surabaya City has received own national and international praise for the achievements of urban policies ". (Bunnell \& Miller, 2013).

The above explanation is not the end of the process of political struggle, because politics is a very dynamic thing and the climate is very volatile. The phenomenon of a centralized shed of votes in several groups and easily mapped politically locus makes the optimism increase for every candidate pair of mayors and deputy mayors of Surabaya. Media power, both printed and electronic, seems to be a common thing. This is because the media is an effective propaganda 
tool that can be used as a megaphone or loudspeaker for political campaigns from each pair of regional head candidates in gaining public sympathy from Surabaya.

\section{Socio-Political Analysis in the Surabaya Mayor Election Map for the 2015-2019 Period}

Surabaya becomes a target for many political parties because it relates to the potential sociocultural and economic potential. In addition, Surabaya is considered as one of the barometers of political power in Indonesia and as the second-largest city after Jakarta. This made Surabaya a city that was contested by all political parties.

If we look closely at political parties and leaders who win the elections in Surabaya, they will benefit from political and economic aspects. Surabaya became a business center for Eastern Indonesia and the center of the source of political power in East Java. Surabaya is also the center of information because all the media were in Surabaya. Based on the explanation and data above, the public can judge from the geographical point of view of the city of Surabaya which has great potential. From a political and economic standpoint Surabaya attracts all people to compete to become regional heads. Surabaya is a national political barometer after Jakarta. In addition to benefiting the head of the region, the benefits of winning political parties will also receive political and economic compensation. Bureaucracy and politics are inseparable parts because politics and economics have become political laws.

From the political context, the regional head that can control the city of Surabaya will control the supporting political parties. Seeing the contestants from previous years, various winning strategies are needed to gain potential votes in Surabaya area. The winning strategies and concepts built in this paper are based on political marketing. The concept of political marketing offered is a synergy to build a constituent power base by building the concept of marketing political candidates who adjust to the willingness and sociocultural potential of the people of Surabaya.

Based on data that is gathered, related to political dynamics and leadership ahead of the election of new mayors, a crucial issue emerged in Surabaya, is the need for refresher leadership. Surabaya needs alternative leaders who have a strong vision to accommodate young communities that have the potential to further advance Surabaya creatively and democratically. If it were examined through media text studies, it can be concluded that current political leadership is too concerned with the issue of tension between elites and tends to be 'one-man show'. The 2015 data shows the number of young people in Surabaya reaches around one million. The population in Surabaya continues to increase every year in line with the increase in urban residents who complain about their fate in the City of Heroes. This turned out to be a problem and caused new problems with the explosion in unemployment. The unemployment problem is partly filled by young people. Those who have just graduated from university find it difficult to find job because of limited employment and intense competition with urban residents.

The variety of data and the potential and diversity of public in Surabaya are the basis for the formulation of a winning strategy for the candidates for the mayor of Surabaya that is currently being carried out. In political communication activities to win candidates who are carried out, the analysis model stages are needed as follows: 1) Analysis of audience and their needs; 2) Determination of communication goals or objectives; 3) Design strategies that include: 
communicators, channels (media), messages and recipients; 4) Determination of management goals (management objectives); 5) Implementation of planning that includes: the number of funds, sources of funds and time; and 6) An evaluation which includes: formative evaluation and summative evaluation.

\section{METHOD}

Political mapping is done by using scientific methods so the results are valid, unbiased and accountable. There are several social research methods commonly used to carry out political mapping (World Bank, 2007), namely: 1) SWOT Analysis; 2) Focus Group Discussion; 3) In-depth discussion (interview); and 4) Survey.

SWOT analysis is an analytical method that used to analyze strengths, weaknesses, opportunities, and threats that must be done to achieve goals (Berg, 2013). Through this analysis, the candidate can get an idea of what is the strength or excess compared to other competitors. This analysis also provides an overview of the weaknesses that an individual faced compared to other competitors. With this information, the candidate can see if there are still gaps or opportunities for success. The extent to which opportunities exist to win. This SWOT analysis is a simple and relatively inexpensive analysis model. This analysis can be carried out by candidates by involving several people he/she trusts. It was recommended that candidates do not involve too many people, just a maximum of five people who are considered to have the capacity. This SWOT analysis should be carried out in an office meeting room or a comfortable place, not too crowded and available office stationery.

SWOT analysis is a very minimal mapping method that must be carried out by candidates. The disadvantage of this analysis method is that many people use assumptions as data. For example, candidates often conclude from the SWOT analysis in the form of having a large amount of support from community leaders. Candidates have to make sure if it is not the assumption that community leaders have supported it. There is no data verification from the community leaders. Therefore, most of the SWOT analyses conducted by candidates are biased and tend to only strengthen their way of thinking.

To set a strategy, a SWOT model can be used, as an equipment for analyzing (Berg, 2013). SWOT stands for: $\mathrm{S}=$ Strengths - Strengths owned by the party; $\mathrm{W}=$ Weakness - weaknesses in the party; $\mathrm{O}=$ Opportunities - Opportunities that the party might get; and $\mathrm{T}=$ Threats - Threats that can be encountered by the party.

\section{RESULT AND DISCUSSION SWOT Placement on Mapping Battlefields in Surabaya}

Mapping an opponent is a variety of information about the strengths and weaknesses of opponents. In the context of regional elections, candidates are required to map those who are rivals. This kind of mapping is ideally carried out well in advance of the elections and is carried out several times before the elections. The mapping of the opponent does not only concern who is the competitor but also concerns the strengths and weaknesses of each. For example, data about who and where the support base of each competitor. Candidates can determine the steps needed, such as determining who might be invited to join the coalition and who the most severe rival. It is determined in areas where candidates must concentrate fully and take votes on the competitor's base. By recognizing the battlefield, we can determine what strategic steps need to be taken. In the context of regional elections, the battlefield is interpreted as a contemporary social-political condition 
of the people in the regional elections. Candidates must fully understand the characteristics of voter behavior. For example, understanding of voter tendencies towards money politics, loyalty to parties, tribal sentiments and so forth. In general, there are three social and political maps that must be understood by candidates, namely: social network maps, voter behavior maps, and communication media maps.

Social network maps discuss the existence of social organizations, religious organizations, youth organizations and even organizations related to kinship and bureaucracy that has power in a region (EPA, 2002). The use of the concept of social network maps becomes important in a political context, especially for candidates who want to be elected as heads of government both locally and nationally to form the right mobilization tool. By knowing and understanding the map of social networks that have a significant influence, a candidate for head of government can target what social organizations can be used as an appropriate mobilization support tool. Social organizations in this context are social organizations that have large numbers of masses and a wide area of social organization. It can be interpreted that if the number of 50 per cent voters are a member of a social organization, it is possible for candidates who are dominant in the operational area of the organization to have the opportunity to win regional head elections.

The youth figure that appears as a public figure and has power has a significant potential victory. Characters in the regions also show that organizations that are deeply rooted in and have networks tend to have the most votes. In the case of elections in Surabaya, several candidates sought to fight for "blessing" or strong relations with local leaders and scholars who had a strong mass base in winning the elections. This is because Surabaya is the center of the cleric movement which has a potential mass base among santri (students), even in a time the term blessing of the kyai langitan (cleric) continues to echo during the election season.

For the winning team, the sociopolitical situation can be learned by mapping the behavior of the voters (Mair \& Smith, 1990). In the case of Surabaya, it can be reflected through the voter participation numbers that can be obtained from the recapitulation of data from the General Election Commission. This data generally contains patterns of behavior, attitudes, and opinions of the general public in the area. Through mapping his political behavior, the candidate can learn how the political behavior of the people who are his constituents. This mapping also includes how the community views the candidates' personification and their competitors. The significance of the use of political behavior maps of voters will later reveal various behavioral differences based on regional categories, social segments, education levels, economic levels, and even affiliated organizations (Mair \& Smith, 1990). The urgency of mapping this behavior is needed if a candidate wants to know how opinions and attitudes of groups of farmers, women, youth, laborers, party cadres and other community organizations. Through this mapping, candidates can determine specific strategies that are oriented to specific regions and social segments. As for other benefits of voter behavior mapping, candidates can find out the objectives and willingness of constituents in their candidates. Just as if the community expects a clean and religious mayor, a candidate can build his concept and imaging strategy according to the expectations of the community.

Mapping Media Communications in 


\section{Message Management in the Surabaya Region}

Discussing how the communication media maps, the candidates must specify the media data regarding communication media that effectively influence the community in their region. The communication media category involves various types and forms of communication media from media outside the space of banners, billboards, posters, and various souvenirs. Categories of electronic media from radio, television, film to face-to-face strategies. Personal media from hand-phones, various categories of social media services that is not distant from the current millennial voters (Craig, 2004). In certain areas, even candidates must prepare traditional forms of communication media that are a favorite of their constituents such as reog, shadow puppets and other cultural performances. The ability of the winning team in determining media variations is the potential for candidates to attract the masses and build closeness to their voters. Determination of the media can give birth to a unique strategy as well as selling points for a politician.

Determining media strategy as an amplification of campaign strength for a region must be carefully formulated. Given the allocation of funds must be measured by the impact that must be taken carefully. This means that not all communication media must be used. But choosing the right media based on how much influence it has on the region is an important issue. Therefore the function of the communication media map becomes an obligation considering that a candidate must be able to select the communication media that must be used as well as the target. This information is a crucial point because the media has varied characteristics. The characteristics of outdoor media such as billboards, banners, and posters can influence voter cognition.
Outdoor promotions are believed to be still capable of boosting popularity but are weak at the same time arousing affection and relationship. Given these two aspects is a force that increases the level of electability of political marketing. Reflecting on the case of the mayor's election in Surabaya, the candidate for mayor was able to build the potential of print and electronic media. One reason is the strategy in reading national media maps in Surabaya. Various national media have the potential of media business conglomerates that network with the media industry in Jakarta.

Beyond the power of the media, the personification of political candidates is the most important asset. Candidates must develop strategies and conceptions that can build and develop effective messages while taking into account the following aspects: 1) Having a message in a structured and systematic manner; 2) Having competence in arguing logically, having a factual argument in supporting a material presentation; 3) Has the power of public speaking, in the form of language intonation (vocals) and managing body movements that support message management; and 4) Able to make rhetoric in front of the audience head to head. Given the ocean of mass is different from the character of the media. Candidates are required to be able to build the art of speaking politely and smartly to lead the audience's trust.

\section{Marketable Branding as a Marketing Solution for Surabaya Mayor Candidates for 2015-2019}

In political marketing, there is an important aspect, namely placement or place. The placement aspect has a close relationship with the way a political institution is present or spreads and the way political institutions communicate with potential voters. Political campaigns must be able to touch all levels of society. 
Factors that support the achievement of this goal are by segmenting the public, where we can find discussions about this study in political marketing activities. One form of political marketing is political campaign activities. Political campaign activities should ideally be able to touch all levels of society. To realize this ideal condition is not an easy thing. A method or strategy is needed to be able to touch all levels of society, which by many experts are known as public segmentation (Smith \& Hirst, 2001). Political institutions are expected to be able to identify and map the structure and characteristics of the community. Data related to mapping can be raised geographically. The specific identification is done by reading population concentration and its spread in an area supported by its geographical conditions. Mapping activities are generally carried out demographically, starting with voter groupings based on age, education, employment, social class, level of political literacy, religion and ethnicity. Mapping activities are also needed based on the constituency of the voters to know the amount of traditional support, the amount of support from other parties or candidates, even to find out the floating mass. The data makes it possible to estimate the number of white groups.

We can relate the situation above to assumptions about distribution systems which are interpreted as a network that includes people and institutions related to product distribution to the wider community (O'Shaughnessy, 1995). This situation is inherent in political activities that place the community able to feel and access political products more easily. Whereas in the political world, the distribution or flow of political products is closely related to the mechanism of the penetration of political products even to remote regions. The public must feel that certain contestants' political products are superior to other contestants.
Determination of promotional media including newspapers, TV, radio, internet, magazines, brochures, pamphlets and posters in the regions is one form of political distribution. Media promotion must also be strengthened by determining regional visits. This activity is not a simple problem because it involves how a political product is distributed through the media or promoted directly to the community. Media promotion contains marketing elements and must be considered in political distribution activities.

The implementation of marketing activities in politics makes marketing not only a matter of advertising and political communication. Moreover, political marketing is placed as a comprehensive approach (Lee-Marshment, 2001). Referring to the Marshment of a political institution when formulating political products, compiling campaign programs and political communication, segmentation strategies to the efforts to meet the needs of the society to the calculation of the price of a political product. Segmentation and formulation of political issues also take into account the socio-cultural conditions of the geographical region and its demographics.

\section{Segmentation and Positioning Approaches}

The entire mix of the marketing mix that has been discussed before, must synergize with the segmentation of the representation of certain community groups. As an illustration, community groups are happy with cultural activities and regional art performances. The form of political socialization generally follows the tastes and segmentation of the community. For example promotions through shadow puppet show, ketoprak, ludruk and so on. This follows the candidate's marketing approach where each characteristic demands a different 
approach. Approach techniques used for certain groups are not necessarily the same as the characteristics of other groups. The next goal is intended for development with the intended population. How much the political message conveyed and received by the community is very much determined by how precise the choice of language, the type of media, the delivery technique and the precise form of communication in the real conditions of the community.

Segmentation in the form of mappingis an important factor, considering that political institutions must always be present in various characteristics of voters. The interpretation of the presence or absence of a political institution is always defined as physical existence. One of them is a visit to remote areas. The presence here means that political institutions are able to be a solution to the problems faced by the layers of society. Political institutions must be able to create programs that can accommodate all layers in order to get support. In this case creating solutions to the problems of professionals with problems faced by farmers and fishermen have certain differences. Likewise the way political institutions treat traditional supporters and floating masses has different strategies.

Reading the case of segmentation for the Surabaya region can be analyzed by referring to the thinking of (Smith \& Hirst, 2001). It is said that political institutions need to do political segmentation. According to Smith, the need for segmentation is based on several things, including, not all market segments must be entered. This statement means that only market segments that have a significant size and number should receive special treatment. Next, political party resources are not unlimited. Political parties must carry out priority activities given the limited resources. The next assumption, related to the effectiveness of political communication programs. Each segment has various characteristics. We need an approach that must be different between those directed at one group of people with another group. The next stage is the segmentation that must be done in the contestation of political parties. There must be an analysis that distinguishes a competitive strategy between a political party and its competitors. This will make it easier for the community to identify and analyze the party they have chosen. When party uniformity occurs, it is generally difficult for voters to distinguish from one another, at this stage positioning plays a role.

There are two inseparable aspects between segmentation and positioning. Segmentation is needed in identifying characteristics that emerge in each group of people. Positioning, on the other hand, is an attempt to place political images and products adapted to the community. Positioning activities cannot be carried out without political segmentation. Without segmentation activities, political parties will have difficulty identifying groups in society. Generally the approach by election contestants is not carried out at the individual level due to cost factors that are quite expensive. So, the strategy that must be done is to collectively target community groups. The community group is divided into individuals who have identities, personalities, hopes, aspirations and goals that have more or less the same dimensions. This situation facilitates the process of delivering political messages in distributing things that tend to be uniform.

Efforts to place the concept of marketing include segmentation, targeting and positioning for prospective mayor candidates in Surabaya are discussed and written in an article (Bartle \& Griffiths, 2001). Referring to both, the important contribution of marketing science in the political domain is activities related to 
segmentation. In segmentation there are two things that can be done. One of them, the basic identification used to segment. There are several methods that can be done in segmenting, from demographic, psychological, to casual-based conditions. After that, political parties need to develop a profile of the results of political segmentation. This profile should include three things.

The first, profile regarding floating mass. Why do political candidates have to understand about the profile of the expanding masses? This is important to do to ensure the number (size) and the underlying characteristics. Generally the expanding masses will wait until the end of the campaign period, then only determine which contestants are chosen. When there are no contestants of their choice, this mass tends to choose to be a white group. This mass has the attitude that choosing or not, does not significantly change their conditions. Factors causing this phenomenon are generally work program offerings that have not answered what the floating mass needs. Therefore, a profile regarding floating mass is needed to know its demands and aspirations. Failure to understand the conditions of the floating group results in the failure of the work program that suits them. The sympathies that must be developed by political candidates must be based on indepth surveys, so that reciprocity can be created.

The second, profile of supporters of political parties. Supporting characteristics as well as sympathizers are needed to find out the reasons for being supporters. Characteristics such as age, gender, type of work, purpose of life, lifestyle, values and norms of life must be possessed. Good mastery and understanding of this data will increase party capabilities. Politics and candidates concerned to be able to serve the political needs of their members. In addition, a detailed supporting profile is also needed to develop work programs that become socialization as well as political issues that are tailored to the supporting characteristics.

The third, profile related to supporting party competitors. Profiles of competitors' party supporters must be drawn up, considering that each contestant is required to enlarge their support base. The strategy that must be done is entering the political competition climate by prioritizing proactive strategies to increase vote acquisition. This is because a political party is always in the shadow of its political competitors and continues to seize support from the profile of traditional voters. Other than that, it does not rule out party members and supporters who cross into the opposing camp. A multi-layered security strategy so that the protection of party assets must be arranged in detail.

If the data regarding the completeness of the profile has been obtained, the next step is to arrange political targeting. To facilitate this step, a standard as well as a measurement reference for each political segment is needed. Measurement parameters can utilize the amount and magnitude of potential voters. Communities with large populations can be potential political targets, because this group contributes a significant vote. Measurement parameters can utilize the significance and effect of the community in influencing the emergence of public opinion. In mass communication activities, contestants can also use the Noelle Neuman model by utilizing the spiral silence technique.

Although the number of community groups does not have a significant magnitude, the potential influence in creating public opinion is very potential. Certain methods are needed to study the influencer community. Considering that not every community is a political target. The consideration 
is the limited resources as well as the effectiveness of the contestants' time. The priority scale in determining and selecting which segments are the political targets is determined by two aspects. The first aspect is the direct effect arising from the political segment, in the form of votes obtained when the general election takes place. The second aspect is the multiplier effects, where the plunge of the community segment increases the number of votes.

If the targeting phase is complete, the next step is to develop a positioning framework for the entire market segment. Positioning involvement is an urgency in political marketing activities (Lock \& Harris, 1996). Positioning activities refer to (Worcester \& Baines, 2006) which describe that political parties and election candidates permanently create positioning through rebuilding policies, images, supporting the birth of various public facilities in infrastructure. Considering that the Positioning stage is very important as a mainstay strategy so as not to be displaced by competitors who carry out similar activities, differentiation must be made in establishing their positioning. This is to make it easy for voters to distinguish between contestants and competitors. A detailed positioning framework regarding political images, political products, and political messages to work programs explicitly encourages the creation of political identity. So that each activity will strengthen the identity building that you want to create.

Positive or negative impressions that are built in the minds of the community are very dependent on how well the positioning process mechanism works. Meanwhile, the next step is to design a marketing mix that has been adjusted to its target. Where each group and its political segments differ in various ways. Each competitor segment will be affected and a reactive process will occur. Therefore, the product determination strategy, form of promotion, price scale and distribution process must be conditioned to adjust the characteristics of existing segments.

The term political climate in the scope of political marketing is often interpreted as a discourse, issue or trend that develops in society. Generally, political issues that develop differ from one region to another. The issue in Jakarta regarding floods and traffic jams is certainly different from the issues in the Riau region related to logging and haze. This situation requires the candidate to understand and be careful and careful about the political issues that are rife in his area. Through reading political issues, candidates are able to determine their campaign themes precisely. Candidates for the Regent of one province in East Java can win the Regional Head Election because it carries a unique and simple campaign theme of kambingisasi ("goatisation"). The issue of kambingisasi is interesting because the Regent candidate is studying employment or unemployment issues that have plagued his region. Almost every socialization of the candidate promises job opportunities and alleviates people from poverty with the help of goats in rotation to be promoted to be managed by the community self-help. However, on the contrary errors in reading political issues can result in candidates becoming "foreigners" who are present in the contestation in the community. In this situation the market analogy in political activity must be read transparently. That political marketing is the same as market law.

In understanding market strategy, market survey capability is needed. What is meant by this market survey is often defined by the term polls or polls. Survey activity is a synergy of research methods which is preceded by in-depth interview techniques of a number of informants to get an illustration in general (Martin, 
2012). When it compared with other methods, then this survey technique is considered the most adequate. Through the poll determination technique, the candidate's success team can gather a number of information needed for winning logistics.

Generally, surveys related to local elections have several terms, such as surveys related to popularity or called the Pre-Pilkada (pre-regional head election) Survey and Political Mapping Survey. The variety of survey labels is intended to reveal the popularity of candidates and political opponents who advance in contestation. The diversity of PrePilkada survey labels tends to connote to surveys aimed at knowing the extent to which pilkada preparations are made. The political mapping survey is generally carried out in more depth. The results of the Political Mapping survey were able to reveal a variety of important things needed by candidates and their success teams. The output of survey activities related to political mapping will be recommended to the buyer to arrange ways to maintain and at the same time increase the chances of a candidate winning the contestation in the regional head election.

\section{Benefits of Candidate Popularity Surveys}

The preliminary survey regarding the mapping of voter behavior and its orientation are political parties and candidates for regional head elections. If a candidate wants to study comprehensively the area of political marketing, then survey data must be ready because it will provide several benefits. Some of the advantages and benefits obtained by candidates are: 1) Candidates will know the bargaining position of the segmentation area; 2) The results of the polls as a scientific evidence tool for candidates in convincing and getting support from political parties and donors, volunteers as well as political machinery that will move to support these candidates; 3) Determine the pair that is under the aspirations of the community, determining the companion tactically and strategically can be based on the results of this survey. Therefore, candidates can analyze those who have the potential to become partners in winning regional head elections; 4) Survey results can increase the efficiency of campaign funds. Candidates can determine the priority scale of the campaign. The allocation of funds can be distributed to the potential of winning areas based on the image of survey data; and 5) The survey results can provide information regarding the form of interesting socialization because a special approach is needed for each particular group of people.

\section{The benefits obtained by Political Parties}

The benefits that are obtained by the political parties are: 1) Tactically and accurately, survey data provides recommendations in determining candidates; 2) Referring to the survey results, political parties can calculate the percentage of a candidate's victory; and 3 ) the party controls the characteristics and political mapping of the regions surveyed on a local scale.

Overall, the analytical capabilities of the survey results reveal the strengths and weaknesses of the candidate. The survey can find out the magnitude of the popularity as well as the electability of candidates at the district, city or provincial level; describe the character of a group or segment of society including religion, social class, ethnicity, age, gender, education, political affiliation based on the sub-district, village supporting each candidate; provide information on how the positive image and negative image of each candidate.

The analytical capabilities of the survey can reveal the potential strengths 
and weaknesses of the opponent by providing determinant variable information for candidates against opponents. Strategically it records the support base of the opposing candidates. It drawn from various aspects of religion, ethnicity, age, gender, education, political affiliation, sub-district, village, social class. The survey expressed voter behavior to provide information about the voter orientation, based on sociopsychographic conditions, and obtain data on the distribution of loyalty and voter sentiments to other parties and social organizations. It obtain information and input from the public regarding important information in the formulation of winning strategies; determine the category of effective communication media; know and measure the intensity of local media as a basis for determining media-political spending; capture and map various political discourses to obtain and know the campaign theme desired by the community; understand the problems of each social segment of society; and capture various community inputs regarding the winning steps

The various approaches above are conceptual and theoretical synergies which are expected to be able to direct the socialization mechanism in a planned manner. Political communication carried out by political candidates is ideally through stages of good and comprehensive planning. So, the efficiency and management of financial management, logistics, resources and assets can potentially be managed properly.

\section{CONCLUSION}

The political phenomenon in the country is currently draining attention, given the practice and strategy of winning are opposed to the principles of political economy. Various techniques are carried out as a form of building mass loyalty and increasing the chances of victory.
The discussion about the practice of political marketing has a deviation from commercial marketing; this is because the concept of political marketing does not "sell" political parties or candidates to voters. Political marketing offers a concept of how political parties or candidates can develop programs that correlate with actual problems. At this stage the definition, data collection, quality of survey data, management and management of voters and constituents are crucial. Finally, political marketing activities are defined as techniques in maintaining two-way relationships with the public.

The discussion above points to some message formulas, that; First, political marketing can be defined as "technique" in offering and promoting political parties as well as political candidates. The second formula, political marketing formulates voters as subjects, not objects. A special approach is needed by increasing communication persuasion. The third formula, the variety of problems faced by voters is the first step in preparing work programs to improve the positioning of candidates and political parties. The fourth formula, activities in political marketing do not guarantee victory but they provide tools to build relationships with voters. As an instrument, its instrument capacity becomes reliable when integrated with communication techniques and comprehensive marketable branding concepts.

\section{REFERENCES}

Bartle, J., \& Griffiths, D. (2001). Political Communications Transformed: from Morrison to Mandelson. Basingstoke: Palgrave Macmillan.

Berg, C. F. van D. (2013). Strategic Planning for Political Parties: A Practical Tool. Amsterdam: International IDEA and NIMD.

Berita Metro. (2015, October). Pilwali 
Wahyuni Choiriyati, dkk. Marketable Branding in Surabaya...

Surabaya, Kunci Kalahkan Petahana Ambil Suara Golput. Retrieved from http://www.beritametro.co.id/jatimmemilih/pilwali-surabaya-kuncikalahkan-petahana-ambil-suara-golput $\% 0 \mathrm{~A}$

Bunnell, T., \& Miller, M. (2013). Urban Development in a Decentralized Indonesia: Two Success Stories? Vancouver: Pacific Affairs.

Craig, G. (2004). The Media, Politics and Public Life. Victoria: Ullen \& Unwin.

EPA. (2002). Community Culture and the Environment: A Guide to Understanding a Sense of Place. Washington D.C: Office of Water.

Lee-Marshment, J. (2001). The product, sales and market-oriented party - How Labour learnt to market the product, not just the presentation. European Journal of Marketing, 35(9/10). Retrieved from doi: 10.1108/EUM0000000005959

Lock, A., \& Harris, P. (1996). Political Marketing Vive Jla difference. European Political Marketing (Vol 30 No.).

Mair, P., \& Smith, G. (1990). Understanding Party System in Western Europe. New York: Frank Cass.
Malang Post. (2015). Menangkan Serasi, Partai Demokrat Ajak Parpol Non Pendukung. Retrieved from http://www.malang-post.com/ nasional/107057-menangkan-serasipd-ajak-parpol-non-pendukung

Martin, A. J. (2012). Young People and Politics: Political Engagement in The Anglo-American Democracies. New York: Routledge.

O'Shaughnessy, J. (1995). Competitive Marketing: A Strategic Approach. New York: Routledge.

Smith, G., \& Hirst, A. (2001). Strategic Political Segmentation: A New Approach for a New Era of Political Marketing. European Journal of Marketing, Vol.35, No(No. 9), 1058-1073.

Worcester, R. M., \& Baines, P. R. (2006). Voter Research and Market Positioning: Triangulation and its Implications for Policy Development, In Davies, P,J \& Newman, (Eds), Winning The Election With Political Marketing. New York: Haworth.

World Bank. (2007). Tools for Institutional, Political, and Social Analysis of Policy Reform. Washington D.C: The World Bank. 